InOdia $\quad \begin{aligned} & \text { InMedia } \\ & \text { The French Journal of Media Studies }\end{aligned}$

7.1. $\mid 2018$

Visualizing Consumer Culture

\title{
Lachrystal D. Ricke, The Impact Of YouTube On U.S. Politics
}

Lanham: Lexington Books, 2014

\section{Elisabeth Koechlin}

\section{OpenEdition}

\section{Journals}

Electronic version

URL: http://journals.openedition.org/inmedia/1328

DOI: 10.4000/inmedia. 1328

ISSN: 2259-4728

\section{Publisher}

Center for Research on the English-Speaking World (CREW)

\section{Electronic reference}

Elisabeth Koechlin, «Lachrystal D. Ricke, The Impact Of YouTube On U.S. Politics », InMedia [Online],

7.1. | 2018, Online since 20 December 2018, connection on 24 September 2020. URL : http://

journals.openedition.org/inmedia/1328; DOI : https://doi.org/10.4000/inmedia.1328

\footnotetext{
This text was automatically generated on 24 September 2020.

(c) InMedia
} 


\section{Lachrystal D. Ricke, The Impact of YouTube On U.S. Politics}

Lanham: Lexington Books, 2014

Elisabeth Koechlin

\section{REFERENCES}

Lachrystal D. Ricke, The Impact of YouTube On U.S. Politics, Lanham: Lexington Books, 2014

1 How is the ever-changing landscape of expanding social media and online video sharing changing political communication in the United States? This is the overall question raised in Lachrystal D. Ricke's 2014 book, The Impact of YouTube on U.S. Politics. Throughout this book, Ricke identifies specific areas in which the landscape of political campaigning and communication has been shaped by new internet platforms, and how these platforms in turn shape the political landscape.

2 YouTube is the primary focus of this book because, as Ricke writes, "YouTube is the most trafficked video sharing site in the world...with a substantial impact on the political internet" (9). While Ricke's study of YouTube helps the author illustrate a larger trend of social media's impact on political communication, focusing solely on YouTube is limiting. This exclusive focus does not factor in the other social media platforms which have helped to facilitate the growth of YouTube and its impact on U.S. politics. Therefore, Ricke misses an opportunity to explore the larger terrain and produce a more in-depth or compelling analysis, although her book is thorough.

3 The Impact of YouTube on U.S. Politics was written primarily to illustrate how YouTube "has become a fixture in campaigns and political communication" (17). Ricke's dissection of YouTube as a political communication tool examines the evolution of how both politicians and the citizenry have utilized the platform as a tool for campaigning, debate, communication with the constituency, and engagement among citizens and among politicians. 
Overall, Ricke's purpose in writing this book is to explore the "successful integration of YouTube into political communication strategies" and "some failures on the part of politicians and campaigns to adequately engage the populous via the medium," to "address the overarching question of where the relationship between politics and YouTube may lead in the future" (2).

5 The Impact of YouTube on U.S. Politics begins with the introductory premise that YouTube has transformed political communication from a traditional top-down model, to a more participatory model of communication. This participatory model, referred to as "Web 2.0," is defined as a "conceptualization of the Internet as a platform through which individuals, many with no specialized training or education, are the primary developers of web content" (8). This "interactive, content-rich" environment has shifted the "traditional hierarchies of political communication" in which "politicians, political parties, and campaigns are no longer the sole, or in some cases even the primary, creators and disseminators of political messages" (8). Within this environment, YouTube has shown major growth over the last two decadesparticularly through "the 2006, 2008, 2010, and 2012 election cycles" (2). Due to these factors, YouTube "has become the flagship online video sharing website" with features that "consistently allow it to engage with new and expanding audiences" (11).

6 The first section of the book, entitled "YouTube and Political Campaign Communication", illustrates how YouTube has generally impacted political campaigning in the United States. Ricke shows how campaigns have figured out how to reach "more substantial and more responsive audiences" through "viralability" and "microtargeting" (23). The author delves into the evolution and impact of YouTube on: political message development and image control; political advertising and fundraising; and political debates.

7 In looking at the impact of YouTube on political message development and image control, Ricke explores how "YouTube has subverted the traditional gatekeeping protocols of both the mainstream media and political campaigns" (41). This transition occurred over a very short period of time, as Ricke describes:

In 2008 some major party candidates began using YouTube to announce candidacies and follow up on announcements made via more traditional media outlets. By the 2012 election, YouTube had become a go-to channel for campaigns, with nearly 600 candidates for political office around the United States hosting official YouTube channels (41).

In addition to the political campaign and image control tools that YouTube provides, it also has become a platform for candidates to launch advertising and fundraising efforts. These candidates have found that such online advertising campaigns can "increase interactivity, accountability, iterability, and targeting, making them an attractive compliment to mainstream campaign advertising strategies" (48-49). However, if such advertising efforts were not properly conceptualized, then the messages were lost in translation or proved to be ineffective by "attempting to capitalize on viralability rather than thinking through the elements requisite to effectively disseminate a campaign's message" (55).

In this section, Ricke makes an interesting point regarding YouTube's role in political debates. He says that YouTube's evolving role speaks to the changing media landscape's impact on U.S. political communication as a whole. "Historically, political debates have not overtly welcomed public interaction, with most recent research suggesting that 
debates are created for audiences only in the sense that candidates construct arguments to persuade them, but not necessarily to engage them," he writes. However, in the new era of politics, social media outlets such as YouTube have offered the public "many novel ways to become involved and engaged in this traditionally closed form of political communication" (66).

These engagement-oriented methods of involving the public include "soliciting debate questions online, allowing audience members to submit real-time feedback via social media during live debates, offering downloadable applications for streaming presidential debates, archiving debates for on-demand viewing, and ... live debate streams and live reaction platforms" (67). Integrating these functionalities in political debates "has offered the public a level of interactivity with debates that was once reserved for the political elite," Ricke concludes (67).

In the second part of The Impact of YouTube on U.S. Politics, enttled "YouTube and InOffice Communication", Ricke discusses how YouTube is utilized by elected officials as a platform to engage their constituents. She writes that this investigation of how "elected officials inform and engage their constituents through YouTube" will "inevitably evolve and provide for the expansion of interesting new veins of research" (86). This section specifically dissects the creation and evolution of the White House YouTube Channel during former President Barack Obama's first term in office.

Overall, Ricke posits that "YouTube's wide range of political information allows it to effectively function as a cyberdemocracy platform" (88). She explains that this is the case due to the following:

YouTube enables elevated communication and interaction between elected officials and the constituency, enhances both the access to and delivery of political information, and provides an opportunity to build a more effective relationship between the political establishment and the polity (88).

13 YouTube not only enhances communication, but also allows politicians the "ability to function as their own agenda-builders" (89). Because of this, politicians have begun to explore new ways to take advantage of such tools. This includes the development of: political YouTube channels, through which politicians post "speeches, debates, media appearances, behind-the-scenes footage of their campaigns or day-to-day work, and advertisements" (91); the YouTube Town Hall, which was launched by YouTube in May 2011 as "an online platform through which members of Congress virtually debated and discussed important national issues" (92); and other "enhanced constituency engagement methods" (90).

In looking specifically at the political YouTube channels, Ricke analyzes the White House YouTube Channel (WHYTC), which was launched on January 20, 2009 when former President Barack Obama took office. The WHYTC was created "to engage those coming to the White House website looking for information about the administration" (105). Overall, Ricke finds that the WHYTC "served the dual purpose of humanizing the administration for the public and also elevating the transparency of the government" (116). In setting this standard of transparency for the presidential administration, Ricke, writing from the perspective of 2014, raises an important question that the reader can begin to pick apart today:

As different politicians assume the helm at the White House in the future, it will be exciting to see if they follow in the Obama administration's footsteps with regard to the distribution of information through the WHYTC or revert back to more traditional and closed systems of information dissemination (118). 


\section{Democratic Engagement", discusses how citizens can take advantage of Web 2.0 and} YouTube to enhance their communication with their elected officials and with each other.

"YouTube can offer individuals options for democratic engagement that expand levels of information opportunities for political involvement," Ricke writes, adding that "participation through YouTube can enhance the public sphere, encourage deliberative discussion, and strengthen the public's political efficacy" (121). She cites the importance of this "deliberative discussion" for the citizenry: "Much like politicians seek ways to enhance authenticity, transparency, and access, so too do individuals through their engagement in online communicative behaviors" (121).

In turning to the political engagement which YouTube facilitates, Ricke finds that "the integration of YouTube into political communication has initiated a shift in the public sphere and created new opportunities for the public-at-large to engage in deliberative democracy" (123). She explains that a deliberative and functioning public sphere is vital for democracy. Being that there has been "cybertransformation of the public sphere," Ricke suggests YouTube serves as an online platform which facilitates the kind of debate and discussion necessary for a healthy democracy: "vital for a healthy and thriving democratic state to occur" (127).

While YouTube and other such Web 2.0 technologies can help facilitate a healthy democratic society, Ricke writes "the attitudes and competencies of the electorate, its adherence to important social and political principles, and its participation in the maintenance of a vital and inspiring democracy" are equally important (161).

Ricke goes on to identify the limitations that YouTube has in facilitating such a democracy. Namely, one such limitation is the digital divide, defined as "patterns of access inequality based on socioeconomic considerations" (176). In the United States, this divide means that a "marginally substantial percentage of the American population still does not have the physical access and/or necessary technological skills to engage in online political behavior" (176). The result of this may be no better than the kind of democracy that existed prior to the existence YouTube, writes Ricke:

Instead of online politics mobilizing a more inclusive, emancipatory, and egalitarian populous, the Internet may instead be promoting the spread of viral politics that privileges an elite and competitive constituency. With a few heavily relied upon websites dominating a large portion of political discourse, the Internet may not be so different than historical political structures that reinforce traditional inequality in participation and societal influence (177).

Ultimately, "the political Internet will likely never live up to the romanticized version of what could be and public political engagement and deliberation will likely never take place at the levels in which many scholars would consider transformational," Ricke writes (182). However, YouTube has still contributed to facilitating a more interactive public sphere and "can be useful for reinvigorating an evolving and expanding public sphere, providing a base for more diverse political information and deliberation, and establishing a venue for a more emancipated electorate" (182). This is the impact of YouTube on U.S. politics. As for what's next, Ricke concludes, "there is no way to correctly speculate on the concrete role that YouTube will play in the future of Unites States' politics" (182). 
21 Overall, The Impact of YouTube on U.S. Politics provides a thorough look at YouTube's impact on political communication. Although Lachrystal D. Ricke's exclusive focus on YouTube is fairly limiting, the book thoroughly illustrates what the impact of YouTube has been on U.S. politics, as the title indicates. Therefore, it has succeeded in achieving its goal.

\section{AUTHORS}

\section{ELISABETH KOECHLIN}

Université Sorbonne Nouvelle Paris 3 